に伴い非金属介在物が増加するのでディンプルの破面単 位は小さくなる。この意味においても溶接金属を低 $\mathrm{Si}$ 低 O 組成とするのが望ましい．

（4）焼もどしによる溶接金属の軟化は，Si 量が多い任 ど迕延する。

(5) $\mathrm{v}^{\mathrm{E}_{-196}}$ のO 量化対す万资化挙動は，溶接金属中 固溶 $\mathrm{Si}$ 量と非金属介在物の生成量とのバランスにより 説明できる。

(6) 適正烍むどし温度 $590^{\circ} \mathrm{C}$ は，溶接金属の true $\mathrm{A}_{\mathrm{c} 1}$ 点直上の温度に相当し, 残留オーステナイト晴は最高値 を示すが，次の理由によりこれのみが跑性改善の要团で はないと管えられる。

i）低 $\mathrm{Si}$ の亡き残留オーステナイト量が 1.4〜5.6 \%の闆で変化しても ${ }_{\mathrm{v}} \mathrm{E}_{-196}$ はほとんど変化しない.

ii）高 Si ほど残留オーステナイト量は増大するが， ${ }_{\mathrm{v}} \mathrm{E}_{-196}$ は逆低下する。

\section{参考 文 献}

1) C.E. Witherell, J.V. Peck; Progress in Welding $9 \%$ Nickel Steel, Weld. J., 43-11 (1964), 473s-480s

2）社団法人日本溶接咕会；9\% Ni 銅用洪金浴接材料の实用化に関与 万試驗研究，9NT 委買会報告望 (1975)

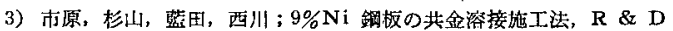
神戸製龬技報，28-4（1978），46-51

4）渡辺，高村，金子，上野，岩䗁，長僧；共金溶接法に上子 $9 \% \mathrm{Ni}$
銅の溶接，日本銅管技款，85(1980)，36-48

5) M. Ushio, F. Matsuda; Effect of Oxygen on Stabilization of Arc in $9 \% \mathrm{Ni}$-Steel GMA Welding, Trans. JWRI, 7-1 (1978), 93-100

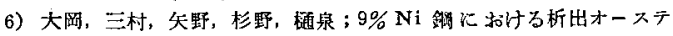

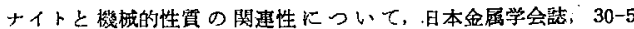
(1966), 442-448

7) K. Suzuki, T. Shimoyama ; Brittleness in Heat Affected Zone $9 \%$ Nickel Steels for Low Temperature, Mitsubishi Technical Bulletin, MTB 010027 (1965)

8) 阿草, 古生, 西山; 未発歨

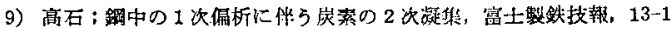
(1964), 1-26

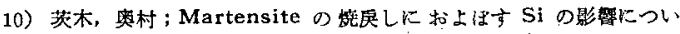
乙(第 1 報)，日本食属学全誌，19-3 (1955)，223-229

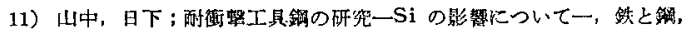
40 (1954), 362-364

17) A.S. Kenneford, T. Williams; Effect of Some Common Alloying Elements on the Breakdown of Martensite in a W.Q. 0.35\% Carbon Steel, J. Iron \& Steel Inst., $185-4(1957), 467-474$

13) G. R. Brophy, A.J. Miller; The Metallography and Heat Treatment of 8 to $10 \% \mathrm{Nickel}$ Steel, Trans. ASM, 41 (1949), 1185-1203

14) D. Hardwick; Some Properties of Steels Containing Nine Percent Nickel, Iron \& Stee1, 34-9 (1961), 414-420

15) C.W. Marschall, R. F. Hohemann, A.R. Troiano; The Characteristics of $9 \%$ Nickel Low Carbon Steel, Trans. ASM, 55 (1962), 135-148

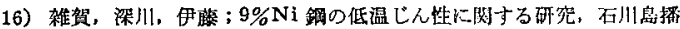
酷技報，13-1 (1973)，17-27

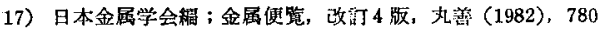

\title{
$60 \mathrm{~kg} / \mathrm{mm}^{2}$ 級高張力鋼の大入熱溶接*
}

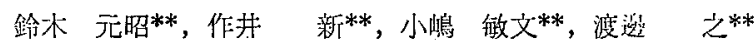 \\ High Heat Input Welding of $60 \mathrm{~kg} / \mathrm{mm}^{2}$ Grade \\ High Tensile Strength Steel*
}

by Motoaki Suzuki**, Shin Sakui**, Toshifumi Kojima** and Itaru Watanabe**

The notch toughness of weld-HAZs deteriorates with the increase in welding heat input. The degradation of notch toughness is caused by the austenite grain growth and heterogeneous transformation products. $60 \mathrm{~kg} / \mathrm{mm}^{2}$ grade high tensile strength steel's weld-HAZ has a stronger tendency to increase the unfabourable transformation products, for example M-A constituent, than $50 \mathrm{~kg} / \mathrm{mm}^{2}$ grade steel's weld-HAZ, because of its higher hardnability. So it was concluded that $60 \mathrm{~kg} / \mathrm{mm}^{2}$ grade steel's weld-HAZ showed lower notch toughness than $50 \mathrm{~kg} / \mathrm{mm}^{2}$ grade steel's weld-HAZ, when the high heat input welding processes were used.

This investigation was carried out to clarify the factors which govern the HAZ toughness and to de- 
velop the $60 \mathrm{~kg} / \mathrm{mm}^{2}$ grade steel suitable for high heat input welding. The results were summalized as follows.

(1) $60 \mathrm{~kg} / \mathrm{mm}^{2}$ grade steel's weldment made by the electrogas arc welding technique showed low notch toughness at the weld-HAZ. These deterioration could be recognized not only at the coarse grained region but also at the fine grained region in $\mathrm{HAZ}$.

(2) When the welding heat input was higher than $60 \mathrm{~kJ} / \mathrm{cm}, \mathrm{HAZ}$ toughness was improved with decreasing the heat input. On the other hand, HAZ toughness became to deteriorate with decreasing the heat input, when the welding heat input was lower than $60 \mathrm{~kJ} / \mathrm{cm}$.

(3) Welding heat input dependency on HAZ toughness mentioned above could not be explained by metallurgical point of view. But it could be interpreted by correlation between notch position and hardness distribution. That is, when the discontinuity of strength existed near the notch, the brittle crack initiated at the notch root deviated and propagated towards weaker region. And obtained values were govrened by the characteristics of weaker region.

(4) The experiment was conducted to improve the HAZ toughness. As a result, HAZ toughness of 60 $\mathrm{kg} / \mathrm{mm}^{2}$ grade steel's weld-HAZ toughness was improved by reduction of carbonequivalent. This improvement was resulted from reduction of $\mathrm{M}-\mathrm{A}$ constituent and formation of pearlite.

(5) The tensile strength of low carbon equivalent type $60 \mathrm{~kg} / \mathrm{mm}^{2}$ grade steel's weld-HAZ had a tendency to decrease at the inverse of heat input. In practice, however it was concluded that lowering the carbon equivalent in a range investigated in this study got no trouble.

\section{1. 緒}

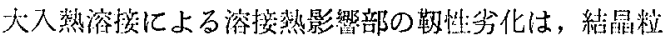
の糊大化と粒界および粒內での不均質連続冷却変態組織 の现成に起团する。非調質型 $50 \mathrm{~kg} / \mathrm{mm}^{2}$ 秋高張力銷に

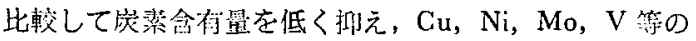
合金元素を添加することによって焼入れ性の问上を図っ ている調質型 $60 \mathrm{~kg} / \mathrm{mm}^{2}$ 級消張力堸の場合，溶接後の 冷却過程がある筷围内で徐冷であればある程，M-A crnstituent $の$ 生成篮変態組織の不均貿化が進行し，それら に起因する脆化が㬝念される。

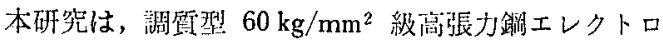

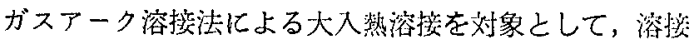
熱影慜部の靱性を支配する各種要因について検街すると とむにそれらに適合する銈材の開発を甞图して行なわ れたあのである。

\section{2. 実験方法}

\section{1 供試鋼}

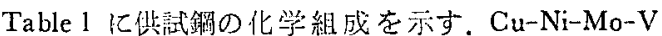

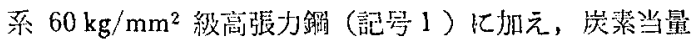
の異なる $(\mathrm{Cu})-(\mathrm{Ni})-(\mathrm{Cr})-(\mathrm{Mo})-\mathrm{V}$ 采 $60 \mathrm{~kg} / \mathrm{mm}^{2}$ 級问

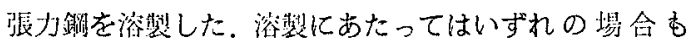

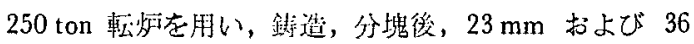

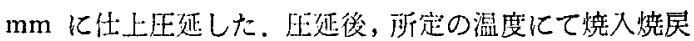
し及理を行い試験に倛した。また比較のため, Table 1 に

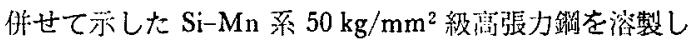

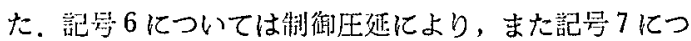

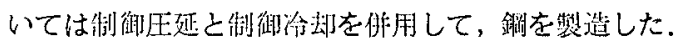

Table 2 亿供試鋼の機珹的性䓄を示す.

\section{2 溶接}

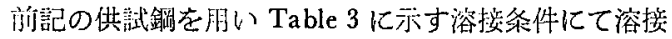
を行った，表中に示されるとうり絸栙ワイヤを用いる高 能率エレクトロガスアーク溶接法によって継手を作製し た，使用した溶按機は Arcos 社製 Vertomatic-SG であ る。溶接にあたっては，表中に示される候䁌内において 電流, 電压, 突き出し軖さおよび開先形状を变化させる

Table 1 Chemical composition of steels (wt.\%)

\begin{tabular}{|c|c|c|c|c|c|c|c|c|c|c|c|c|c|c|}
\hline Marks & C & $\mathrm{Si}$ & $\mathrm{Mn}$ & $\mathrm{P}$ & $S$ & $\mathrm{Cu}$ & $\mathrm{Ni}$ & $\mathrm{Cr}$ & Mo & V & B & $\mathrm{N}$ & Ceq & Note \\
\hline 1 & 0.11 & 0.25 & 1.58 & 0.015 & 0.004 & 0.25 & 0.53 & tr. & 0.06 & 0.04 & tr. & 0.0031 & 0.41 & \multirow{6}{*}{ HT60 } \\
\hline 2 & 0.09 & 0.24 & 1.45 & 0.017 & 0.004 & 0.22 & 0.51 & tr. & $\mathrm{tr}$. & 0.04 & tr. & 0.0026 & 0.36 & \\
\hline 3 & 0.08 & 0.27 & 1.27 & 0.015 & 0.004 & 0.14 & 0.63 & 0.15 & 0.03 & 0.04 & tr. & 0.0026 & 0.36 & \\
\hline 4 & 0.10 & 0.25 & 1.40 & 0.014 & 0.004 & 0.23 & 0.51 & $\operatorname{tr}$. & 0.04 & 0.04 & tr. & 0.0027 & 0.37 & \\
\hline 5 & 0.13 & 0.24 & 1.35 & 0.021 & 0.007 & $\mathrm{tr}$ & tr. & tr. & 0.04 & 0.05 & tr. & N.A. & 0.38 & \\
\hline 6 & 0.08 & 0.27 & 1.23 & 0.014 & 0.003 & tr. & tr. & 0.10 & 0.02 & 0.04 & 0.0009 & 0.0022 & 0.35 & \\
\hline 7 & 0.13 & 0.34 & 1.30 & 0.017 & 0.005 & tr. & $\operatorname{tr}$. & tr. & tr. & tr. & tr. & 0.0032 & 0.37 & \multirow{2}{*}{ HT50 } \\
\hline 8 & 0.10 & 0.29 & 1.63 & 0.016 & 0.003 & 0.14 & 0.11 & tr. & tr. & tr. & tr. & 0.0032 & 0.39 & \\
\hline
\end{tabular}

$\mathrm{Ceq}=\mathrm{C}+\mathrm{Si} / 24+\mathrm{Mn} / 6+\mathrm{Ni} / 40+\mathrm{Cr} / 5+\mathrm{Mo}_{\mathrm{O}} / 4+\mathrm{V} / 14$ 
Table 2 Mechanical properties of steels

\begin{tabular}{c|c|c|c|c}
\hline Marks & $\begin{array}{c}\text { Thickness } \\
(\mathrm{mm})\end{array}$ & $\begin{array}{c}\text { Y.P. } \\
\left(\mathrm{kgf} / \mathrm{mm}^{2}\right)\end{array}$ & $\begin{array}{c}\text { T.S. } \\
\left(\mathrm{kgf} / \mathrm{mm}^{2}\right)\end{array}$ & $\begin{array}{c}\mathrm{VE}-15(\mathrm{~L}) \\
(\mathrm{kgf}-\mathrm{m})\end{array}$ \\
\hline \multirow{2}{*}{1} & 23 & 64.2 & 72.2 & 25.0 \\
\cline { 2 - 5 } & 36 & 64.6 & 72.4 & 28.6 \\
\hline \multirow{2}{*}{2} & 23 & 58.5 & 65.5 & 31.5 \\
\cline { 2 - 5 } & 36 & 59.5 & 67.1 & 25.7 \\
\hline \multirow{2}{*}{3} & 23 & 60.3 & 66.3 & 31.4 \\
\cline { 2 - 5 } & 36 & 60.1 & 67.2 & 29.5 \\
\hline \multirow{2}{*}{4} & 23 & 63.9 & 68.9 & 30.0 \\
\cline { 2 - 5 } & 36 & 60.7 & 69.1 & 27.6 \\
\hline 5 & 22 & 62.4 & 71.8 & 25.2 \\
\hline 6 & 23 & 61.6 & 67.3 & 29.9 \\
\hline 7 & 25 & 40.4 & 53.6 & 27.6 \\
\hline 8 & 25 & 41.0 & 52.6 & 32.7 \\
\hline
\end{tabular}

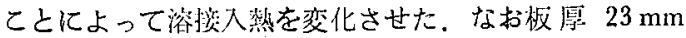
については片面一層溶接，板曆 $36 \mathrm{~mm}$ については阿而 一層溶接を前提とした。

\section{3 識械試験ならびに組織観察}

得られた継手よりシャルピ試験片（JIS-Z 22024 号） を採取し，衝整試験を行った。試験片採取位速ならびに

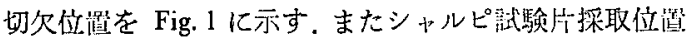

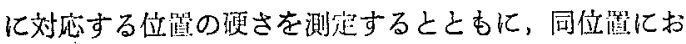
ける微視組織を光学顕微鏡ならびに電一正顕微鏡により雄

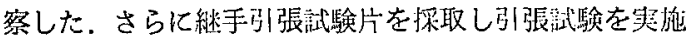
した。

\section{3. 実験結果ならびに考察}

\section{1 調質型 $60 \mathrm{~kg} / \mathrm{mm}^{2}$ 䄲高張力鋼大入熱溶接部の の靬性}

Fig. 2 亿 Cu-Ni-Mo-V 系 $60 \mathrm{~kg} / \mathrm{mm}^{2}$ 級亩張力鎆 (Table 1, 記号 1 , 板厚 $23 \mathrm{~mm}$ ) のエレクトロガスア一

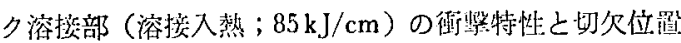

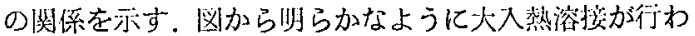

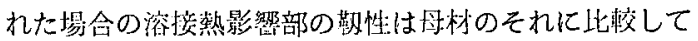

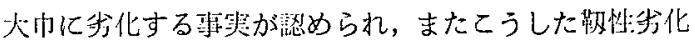

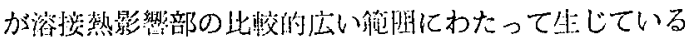
ことがわかる.

Fig. 3 亿溶融晥琹䜌より $2 \mathrm{~mm}$ およひ $4 \mathrm{~mm}$ 潍れた位.

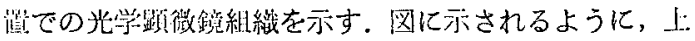

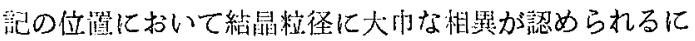

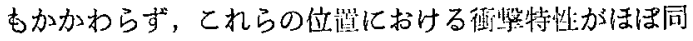

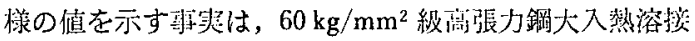

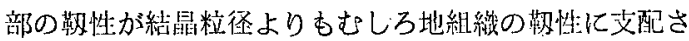
れることを亦している。

\section{2 溶接熱影響部の衙繁特性と硬さ分布}

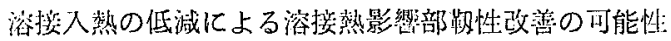

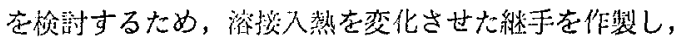

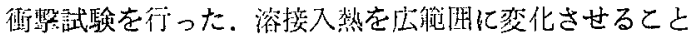
を目的として板㕌 $36 \mathrm{~mm}$ の銿板を用い，Table 3 に亦 したように闒先北状を变化させて溶揬を行った．得られ

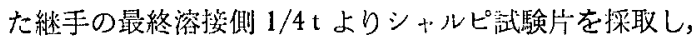
Bond $+2 \mathrm{~mm}$ 位整に圽久を付与して街整試験を行った。

武醫結果を Fig. 4 に示す。 $60 \mathrm{~kJ} / \mathrm{cm}$ を越える溶接入

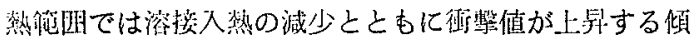

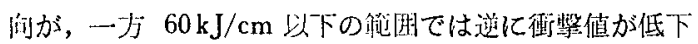

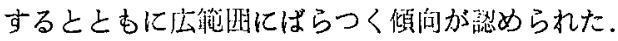

そこでこうした衙整佉の溶接入然依存性を明らかにす

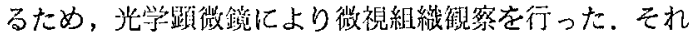

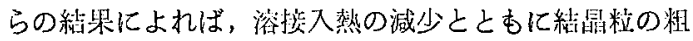
大化加抑制される伐问にあるすのの，糔内はいずれの場 会屯上部べイナイトを主体とする組織を旺しており，浴

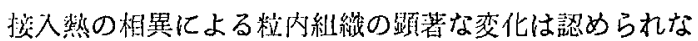
かった，とくに溶接入㷛58および $72 \mathrm{~kJ} / \mathrm{cm}$ にて溶接さ れた䋛手部では，結悲粒俻およびラス状フェライト形状

Table 3 Welding conditions

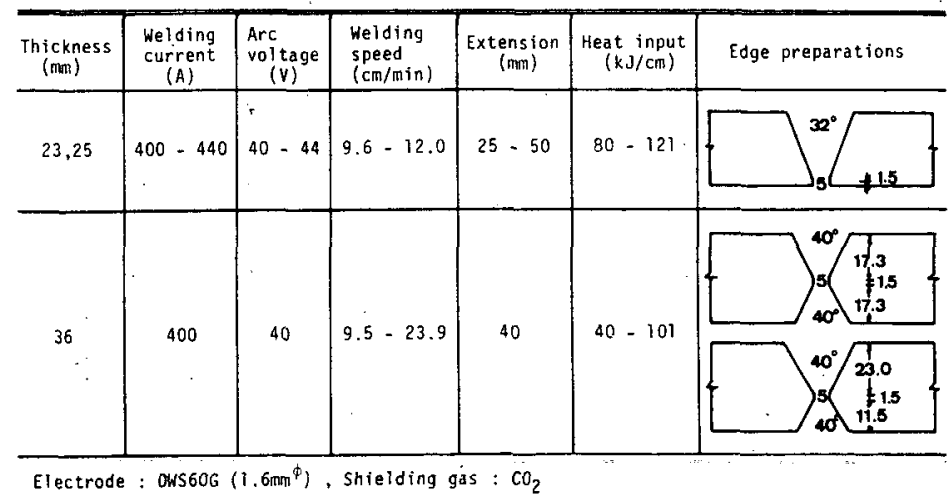




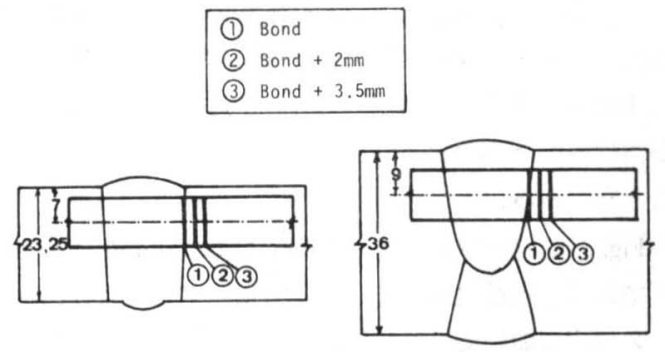

Fig. 1 Sampling and notch positions

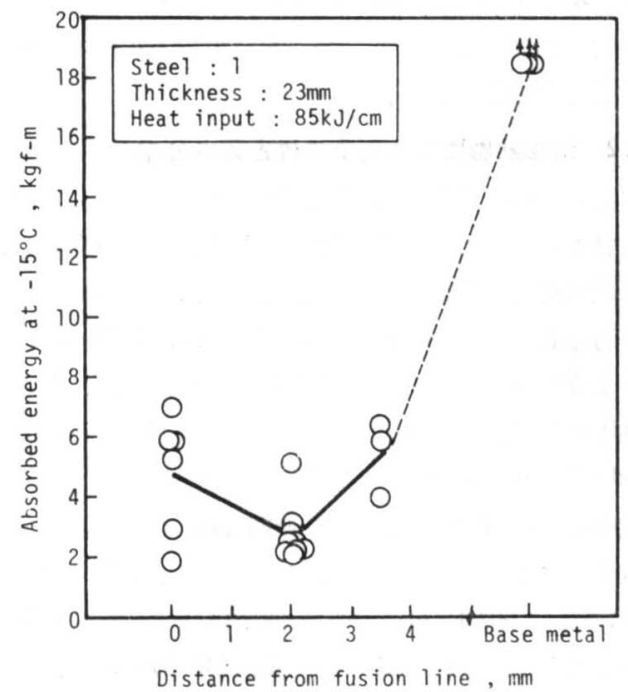

Fig. 2 Impact properties of $\mathrm{Cu}-\mathrm{Ni}-\mathrm{Mo}-\mathrm{V}$ type steel's high heat input weldment

等の粒内組織がきわめて類似しており，そうした組織の 遠いから吸収エネルギー值の変化を説明するととは困難 であった。

そこで溶接継手部の硬さ分布を測定し，それらと衙撃 特性の相関性について検討を試みた。 Fig. 5 に溶接部の 硬さ分布測定絬果を示す. 図中に示される矢印は切欠位 置を，またおのおのの図の上方陆される数字は $-15^{\circ} \mathrm{C}$ での吸収エネルギー值を示している．いずれの溶接継手 において屯溶融境界線加ら溶接熱影響部側へ 1 4 mm 離れた位置に最も硬化した部分が存在し，それらの值と 最低值との差は溶接入熱 $101 \mathrm{~kJ} / \mathrm{cm}$ の場合を除いて 60 $\mathrm{Hv}$ 以上の大きな値となっている。こうした場合の切欠 位置, 最硬化位置および吸収エネルギの相関をみると, 切久位置が最硬化位置よりも溶融境界側にあるとき吸収 エネルギは低い值を示し，一方切欠が母材側に存在する とき得られた吸収エネル:よ゙は高い值を示す傾向が認めら れる. また切久位置と最硬化部が一致する場合にはその 吸収エネルギが高い值を示す場合と低い值を示す場合が ある。
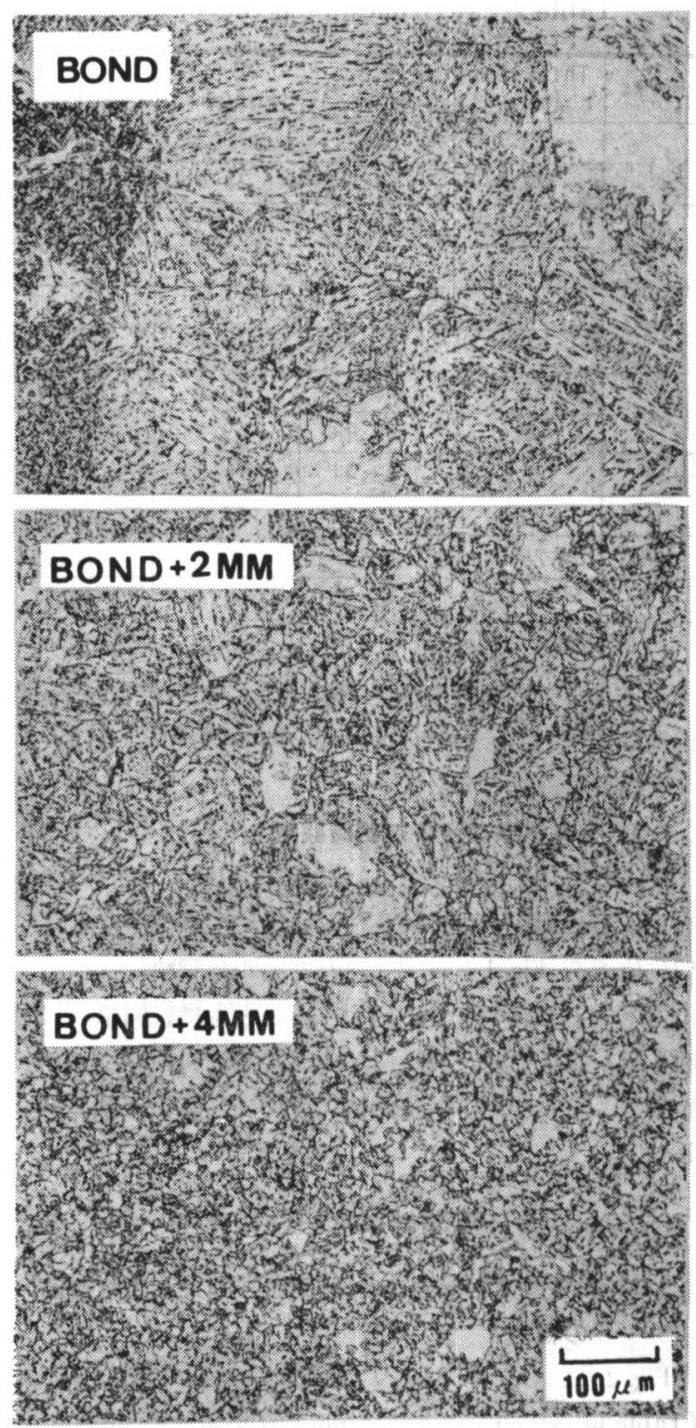

Fig. 3 Microstructure of Cu-Ni-Mo-V type steel's weldment

こうした現象は狭い領域に顕著な強度的不連続が存在 する場合, き裂がより強度の低い側に逸れて伝播し, 得 られる吸収エネルギ值は逸れた側の特性を示していると して説明される。すすなわち, 切欠が最硬化部よりあ母材 側にあるとき，き裂は母材側へ逸れて伝播し高い值を示 すのに対し，逆の場合にはき裂が溶融線側を伝播し粗粒 域の低い勒性值が示されたあのと考えられる。また切欠 位置と最硬化位置が一致する場合には，き裂が母材側へ 逸れた場合には高い值が，溶融境界線側に逸れた場合に は低い值が示されたあのと考えられる。これらはそれぞ れ順に溶接入熱 $58 \mathrm{~kJ} / \mathrm{cm}, 72 \mathrm{~kJ} / \mathrm{cm}$ および $40 \mathrm{~kJ} / \mathrm{cm}$ の 場合に相当する。 


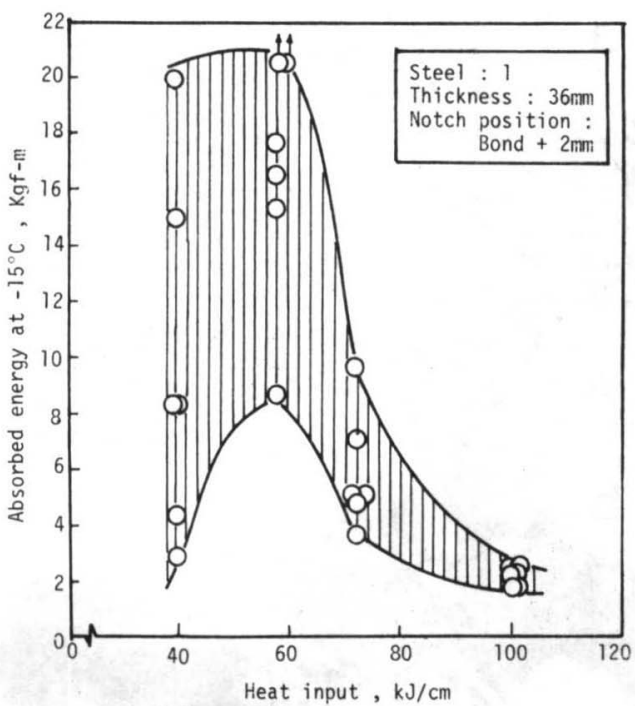

Fig. 4 Relationship between heat input and impact properties of weldments

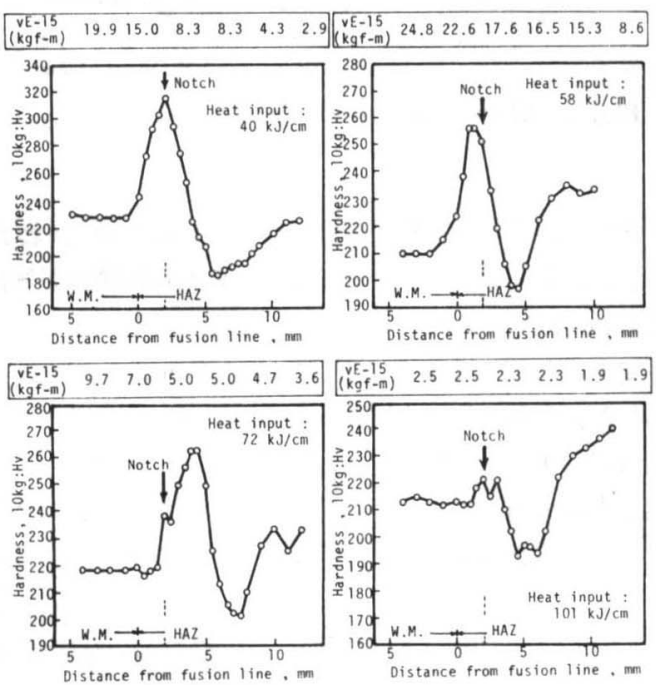

Fig. 5 Hardness distribution and impact properties of weldments

事実, 溶接入熱 $58 \mathrm{~kJ} / \mathrm{cm}$ の場合には母材側へ, 溶接 入熱 $72 \mathrm{~kJ} / \mathrm{cm}$ の場合には溶融境界線側にき裂が逸れる 現象がシャルピ武験片の破断径路観察によって確められ ている. また溶接入熱 $40 \mathrm{~kJ} / \mathrm{cm}$ の場合には, 高い值を 示した試験片では母材側へ，低い值を示した試験片では 溶融境界線側へき裂が逸れて伝播する事寒が確認されて いる.

一方最硬化部と軟化部との硬化差が小さい場合, すな わち溶接入熱 $101 \mathrm{~kJ} / \mathrm{cm}$ の場合にはき裂が逸れるとと なく伝播する現象が確認された。
以上の検討結果から, 切欠の近傍に大きな強度的不連 続が存在する場合に得られる吸収エネルギは切欠位置に おける勒性值を正確に示さない場合があると判断され る.したがって，木実験における切久位置での真の值は 不明であるが, 光学顕微鏡観察結果から判断して, その 值は Fig. 4 に示された值よりあかなり低いあのと考え られ，溶接入熱の低減によってあ勒性值は向上しないあ のと判断される.

\section{3 調質型 $60 \mathrm{~kg} / \mathrm{mm}^{2}$ 級高張力鋼大入熱溶接部の 微視組織}

大入熱溶接を行った継手の溶接熱影㗽部靱性劣化原因 を明らかにし，靯性改善のための指針を得ることを目的 として溶接熱影響部の微視組織観察を行った.

Fig. 6 に溶融境界線から $2 \mathrm{~mm}$ 離れた位置での光学顕 微鏡観察結果ならびに同位置での電子顕微鏡観察結果を 示す．いずれの場合もラス状フェライトに囲まれた島状 の組織（図中A）が钼察される。この島状組織内には Fig. 7 亿示されるように双晶マルテンサイト（矢印B） およびやや灰色がかった領域（四中 $\mathrm{C}$ ) が観察される.

こうした易状組織は Coldon ら1) が観察した M-A Constituent および三村ら2) が観察した島状マルテンサ イトに相当すると若えられる。こうした島状組織がミク 口的応力集中源として作用し地組織の莗性を大きく劣化
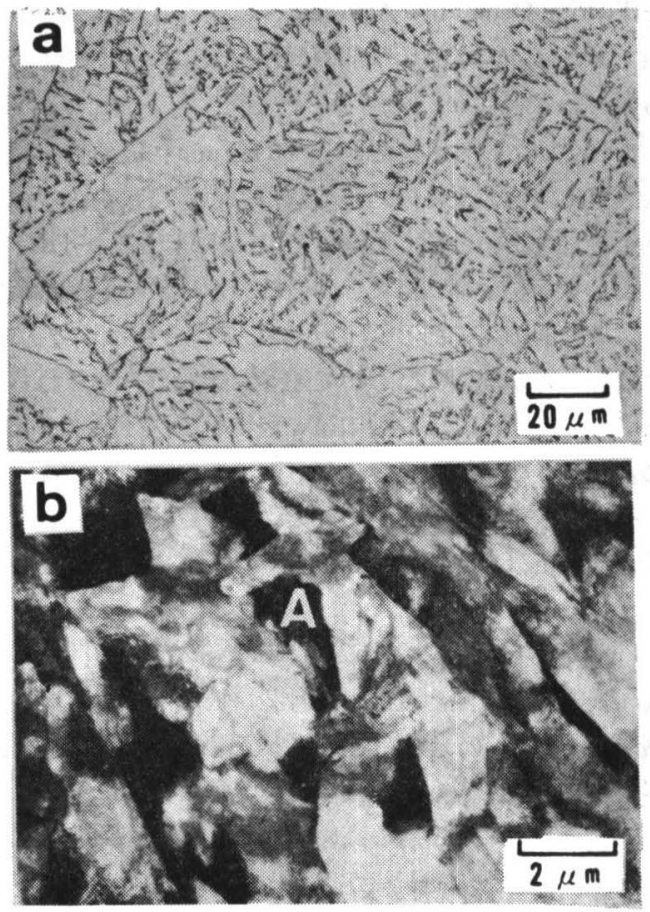

Fig. 6 Microstructure of Cu-Ni-Mo-V type steel's weldment 


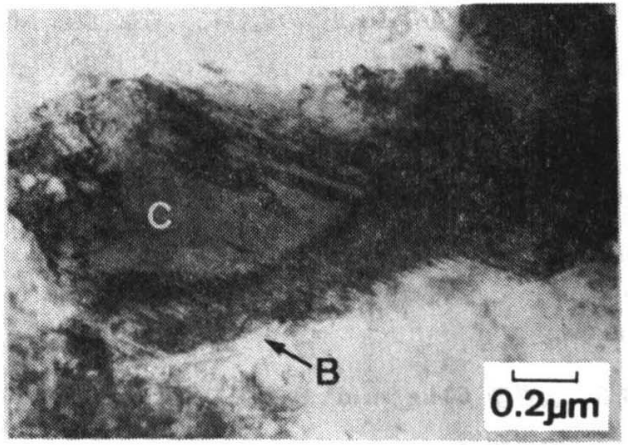

Fig. 7 M-A constituent observed in HAZ

させることは良く知られている事寒であり ${ }^{1-4)}$, 木実験 における溶接熱影響部の大巾な靱性少化の主因はこうし た島状組織 (以下 M-A Constituent と呼ぶ)の形成によ るあのであると判断される.

\section{4 岸素当量の低減による靶性改善}

前項での検討結果から, $60 \mathrm{~kg} / \mathrm{mm}^{2}$ 級高張力鋼におい て大入熱溶接部の靱性改善をはかるためには, M-A Constituent の生成を極力抑制する必要があると判断される Garland ら5) は焼㞍し処理によって M-A Constituent が Ferrite-Cementite Aggregates に変化すると地組織の靬 性が大巾に向上するととを明らかにしている，したがっ て溶接熱サイクル冷却過程において M-A Constituent をFerrite-Cementite Aggregatesに変化させるととが可 能であれば, 溶接熱影響部の䩓性を大巾に向上させ得る あのと考えられる。

これまでに報告されている $60 \mathrm{~kg} / \mathrm{mm}^{2}$ 級高張力鋼大 入熱溶接部靯性改善のための基本思想も島状組織のパー ライト化を狙いとしており, その具体的方法は TiN を 代表とする安定第二相粒子の微細分散による溶接熱影证 部組織の微細化である ${ }^{6-8)}$. しかしながらとうした方法 には著者らが別報》において述べた問題点, すなわち溶 融境界線近傍における微細第二相粒子の溶解現象とそれ にともなう結晶粒の粗大化の危険性を内包している.

そこで本研究では鋼中の炭素当量を変化させ, 溶接热 影響部の組織をフェライト・パーライト化するととを狙 いとした検討を行った.

Fig. 8 亿炭素当量 $0.36 \%$ の $\mathrm{Cu}-\mathrm{Ni}-\mathrm{V}$ 系 $60 \mathrm{~kg} / \mathrm{mm}^{2}$ 級高張力鋼大入熱溶接部（記号 2 , 板厚 $23 \mathrm{~mm}$, 溶接入 熱 $93 \mathrm{~kJ} / \mathrm{cm}$ ) の光学顕微鏡および電子顕微鏡による 観 察結果を示す. 钼察位置は溶融境界線より $2 \mathrm{~mm}$ 離れた 位置である。炭素当量の高い $\mathrm{Cu}-\mathrm{Ni}-\mathrm{Mo}-\mathrm{V}$ 系鋼（記号 1 ) 溶接熱影響部の組織が M-A Constituent を数多く 含む上部ベイナイトであるのに対し, 炭素当量の低い $\mathrm{Cu}-\mathrm{Ni}-\mathrm{V}$ 系鋼（記号 2 ）では伸長したフェライトとラ

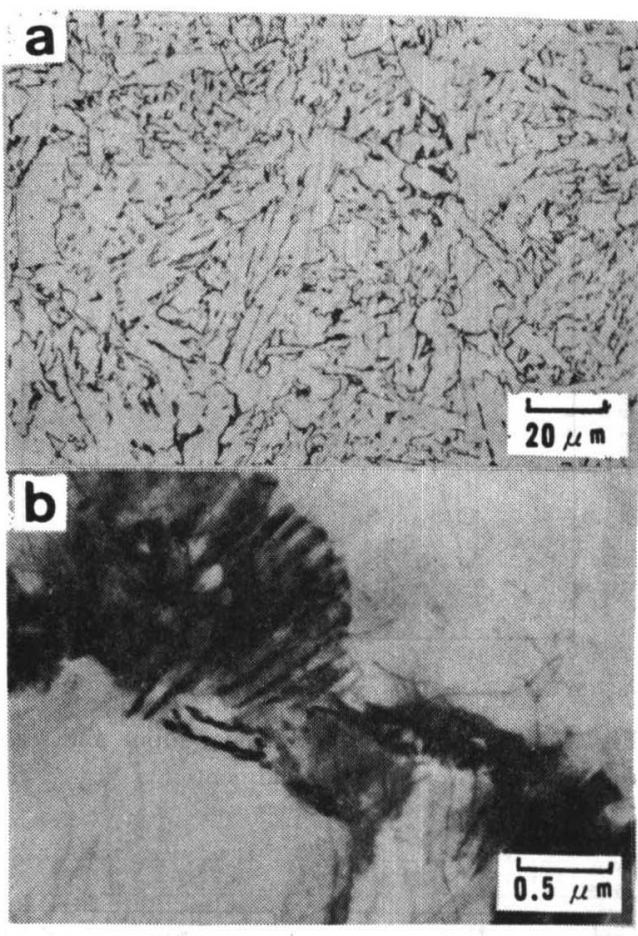

Fig. 8 Microstructure of low Ceq-Cu-Ni-V type steel's weldment

不間に存在するパーライトからなっているととがわか る.ただし, 低炭素当量型 $\mathrm{Cu}-\mathrm{Ni}-\mathrm{V}$ 系鋼溶接熱影響部 において観察された易状部のすべてがこうしたパーライ トであるわけではなく, 一部に M-A Constituent が認め られた。しかしながら炭素当量の高い $\mathrm{Cu}-\mathrm{Ni}-\mathrm{Mo}-\mathrm{V}$ 系 鋼（記号 1) のそれと比較して M-A Constituent の体 積分率は大巾に減少しているととが確認された。こうし た微視組織を示す溶挨熱影響部が高い靱性值を示すとと は容易に推察される。

Fig. 9 に溶接熱影禭部の勒性と切欠位置の関係を示 す。いずれの切久位置においても高い值が得られてお り, またその值も安定している.

Fig. 10 亿溶接熱影響部（切欠位置: Bond $+2 \mathrm{~mm}$ )の $\mathrm{vE}-15$ 之溶接入熱の相関を示す. 溶接入熱が広い範围に わたって変化しているにあかかわらず, 炭素当量の低い 鋼においては, その溶接熱影響部の靱性はほぽ一定の值 を示していることがわかる.

以上の検討結果から大入熱溶接部の鞕性改善に炭素当 量の低減がきわめて効果的であることが確認された.

\section{5 溶接熱影響部の靫性と合金元素}

溶接熱影響部勒性におよぼす合金元素の影響を明らか にするため, 低炭素当量を前提に $\mathrm{Mn}, \mathrm{Cu}, \mathrm{Ni}, \mathrm{Cr}$ 量 の異なる 3 種の $(\mathrm{Cu})-(\mathrm{Ni})-(\mathrm{Cr})-\mathrm{Mo}-\mathrm{V}$ 系 $60 \mathrm{~kg} / \mathrm{mm}^{2}$ 


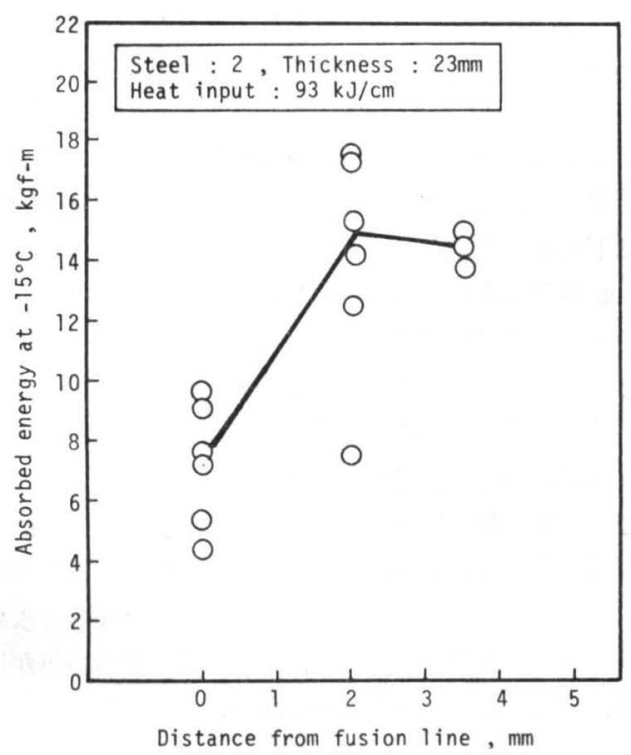

Fig. 9 Impact properties of low Ceq-Cu-Ni-V type steel's weldment

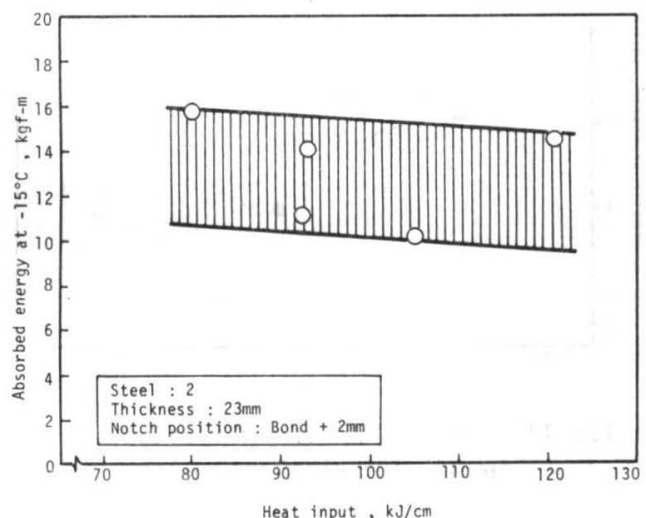

Fig. 10 Relationship between heat input and impact properties of low Ceq-Cu-Ni-V type weldment

級高張力鋼（記号 3〜 5) を用いて溶接継手を作製し， 衙撃試験を行った。試験結果を3.1項ならびに3.4項の結 果を併せて Fig. 11 に示す。四から明らかなように，合 金元素量を变化させた場合にあ大入熱溶接部の靱性は炭 素当量によってほぼ一義的に定まる傾向にあり，60 kg/ $\mathrm{mm}^{2}$ 級高張力鋼大入熱溶接部の靱性に対する合金元 の奇与は炭䒺当量に州着するといえる。

また Fig. 11 中には $\mathrm{Si}-\mathrm{Mn}$ 系 $50 \mathrm{~kg} / \mathrm{mm}^{2}$ 級高張力鋼 について行った同種の茑験結果を併せて示しているが， 同一炭素当量で比较した場合, $\mathrm{Si}-\mathrm{Mn}$ 系 $50 \mathrm{~kg} / \mathrm{mm}^{2}$ 級 高張力鋼溶接熱影㢸部の靱性は $(\mathrm{Cu})-(\mathrm{Ni})-(\mathrm{Cr})-$ (Mo)-V 系 $60 \mathrm{~kg} / \mathrm{mm}^{2}$ 級高張力鋼のそれにくらへて優

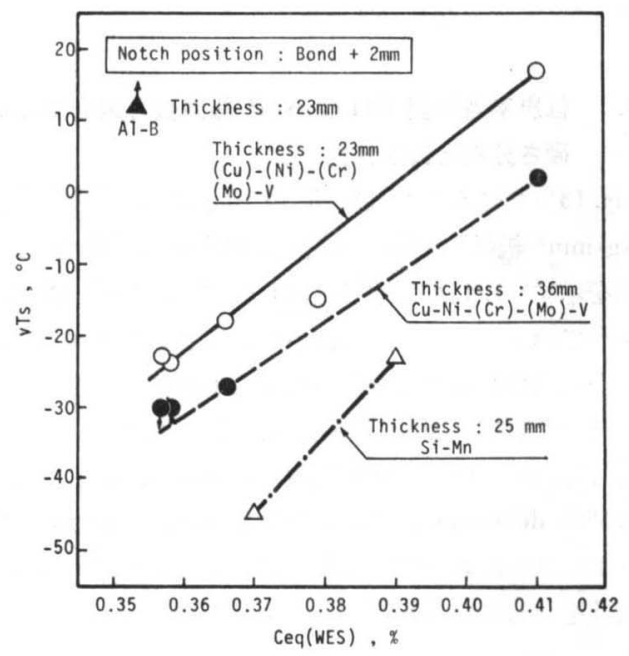

Fig. 11 Relationship between Ceq and vTs of weld-HAZ

れた值を示しており，大入熱溶接により適合する鋼であ るととがわかる．Fig. 12 に Si-Mn 系鋼（記号 6 ）溶接

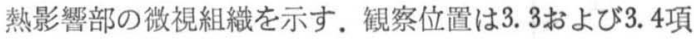
と同様，溶融境界線から $2 \mathrm{~mm}$ 離れた位置である. 図か ら明らかなように, 細粒のフェライト・パーライト組織 が示されており，Fig. 6 および 7 において観察された M-A Constituent は全く認められない.

一方 B の添加による焼入れ性の増大を利用し，炭素当 量および P cm を低く抑えることによって耐割れ性を向 上させた $\mathrm{Al}-\mathrm{B}$ 系鋼についてあ同様の試験を行った. $\mathrm{Al}-\mathrm{B}$ 系鋼においては炭素当量が0. $35 \%$ と低く抑えられ ているにあかかわらず，溶接熱影響部の靱性は Fig. 11 から予想される值よりあ低く，切欠を Bond + $2 \mathrm{~mm}$ に 付与した場合の破面遷移温度は $+19^{\circ} \mathrm{C}$ （板厚 $23 \mathrm{~mm}$, 溶接入熱 $80 \mathrm{~kJ} / \mathrm{cm}$ の場合) であった。 またその微視組 織は Fig. 7 とほぼ同様であった。このととは B の添加 が溶接熱影響部内での上部ベイナイトおよび M-A Co-

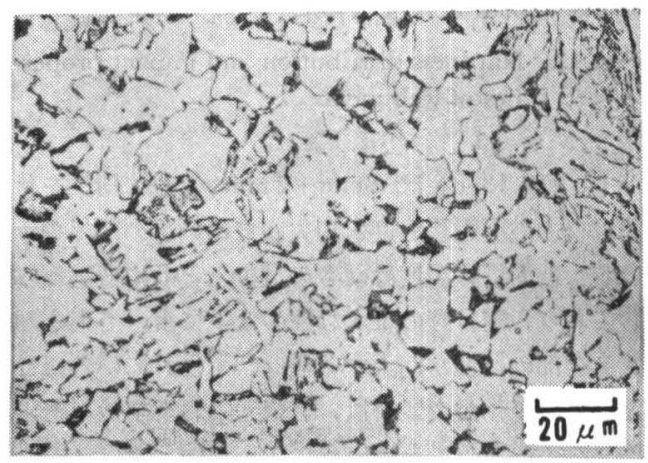

Fig. 12 Microstructure of Si-Mn steel weldment 
nstituent の形成を助長する傾向にあるととを示してい る.

\section{6 低岩索当量型 $60 \mathrm{~kg} / \mathrm{mm}^{2}$ 級高張力鋼溶接部の 硬さ分布と衝般特性}

Fig. 13(a)に3.4および3.5項で示した低炭装当量型 $60 \mathrm{~kg} / \mathrm{mm}^{2}$ 級高張力銅大入警溶接継手部の硬さ分们の 一例を示す. 3.4および3.5垻において検討を行った継手 はすへて溶接入熱の简い条件下で溶接されたものであ り, 図に示される如く著しい強度的不連続は存在しな い，そのため切久底加ら発生した脆性き裂は王応力方向 に対して直角方向任熖しており，3.2 項において述べ たき裂の deviation は認められなかった。したがって シャルピ試験において得られた值はすべて切矢底におけ る勱性を示していると若えてよい。
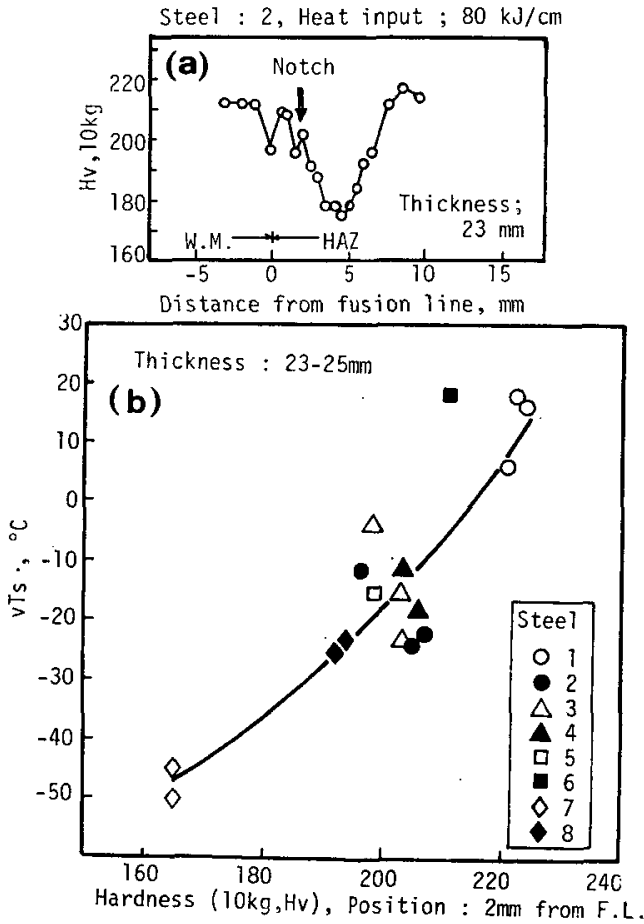

Fig. 13 Hardness distribution and impact properties of weldments

一方, Fig. 13(b) は Bond $+2 \mathrm{~mm}$ 位置に切欠を付与 した場合の破面遷移湿度と切久底での硬さの関係を示し ている。破面遷移温度は硬さの減少之と屯に低温側へ移 行しており，鋼自身の焼入れ性の低下によって大入熱溶 接熱影響部の勒性が向上する項向が示されている．こう した硬さの変化が炭素当量, 合金元素および微視組織と 密接な関係にあることはいうまであない。

\section{7 軟化域と継手強度}

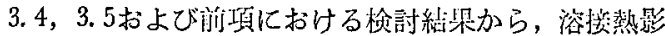

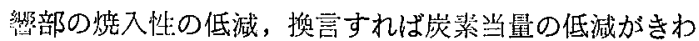
めて有效であることが判明した。しかしながら，烍入橴 民しによって製造される $60 \mathrm{~kg} / \mathrm{mm}^{2}$ 級高張力鋼におけ る炭菜当量の低減は溶接熱影響部の軟化による継手強度 の低下をあたらす傾向にある。

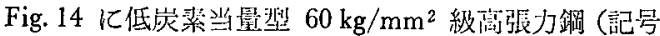

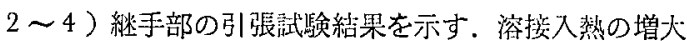
ととあに継手強度の低下傾向が認められる。しかしなが ら，溶努入熱が $90 \mathrm{~kJ} / \mathrm{cm}$ 以下の筑四では母材の強度と ほほ同じ值が得られており，本実験における炭素当量籁 目では実用士問題ないものと考えられる。また Fig. 14 中には硬度行伤から JIS-Z 8413 にしたがって継手备位 啯での強度を推定し，田中ら10)の方法にしたがって求め た推定継手強度を示している，笑測值とそれらの值が比 较的良く一致しているととがわかる。

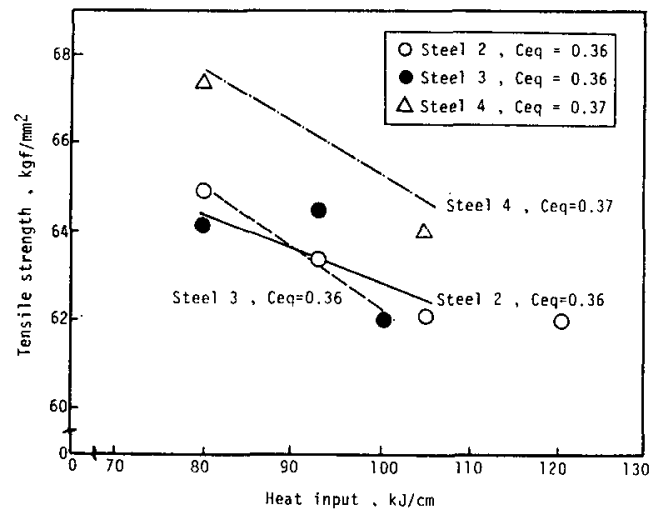

Fig. 14 Relationship between heat input and tensile strength of weldments

\section{4. 結}

\section{論}

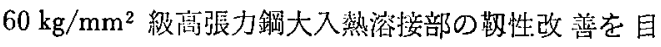
的とした検討を行い，下記の結論を得た。

(1) $60 \mathrm{~kg} / \mathrm{mm}^{2}$ 級留張力鋼大入熱溶接部の欨性 は溶

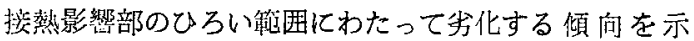
す。こうした靱性の少化は溶接入熱の低隇によって一担 抑例されるが，低入鷲側で再び顕著となる傾向にある。

（2）このような溶接熱影到部の溶接入熱低存性を金相 学的に説明することは困難であり，硬さ分布と切次位置 の相関関係化よって説明される。すなわち著しい強度的 不速続が存在する場合，切欠底加ら発生したき裂が低強 度側へ逸れて伝播し，得られる衝繋值はき裂が晩れた側 の特性に支配されるとして解釈される，したがって上記 の勒性改善傾向はあくまでみかけ上のものであり，溶按 熱影響部の真の靬性值を示すむのではない. 
(3)そこで粒内組織の改善を目的として検討を行っ た.その結果 $60 \mathrm{~kg} / \mathrm{mm}^{2}$ 級高張力鋼大入熱溶接継手の 熱影響部靱性は炭奖当量の低減によって大きく改善さ れ，それらは M-A Constituent の減少と島状組線の パーライト化に起因することが判明した。

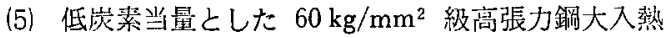
滚接部の強度は，溶接入熱の増大とと屯減少する傾问 にあるが，本実験で取报った炭菜当量䉏囲では契用上問 題のない籍国にとどまる。

\section{参考文 献}

1) A.P. Coldren, R.L. Cryderman et al. ; Symposium "Steel Strengthening Mechanism", Zurich, 1969, 17-44

2) H. Mimora, M. Iino et al. ; IIW IX-629-69

3) 平井; 本誌, 50 (1981) 1，37-46

4) 笠松，高鸣他；跌之鋼，65 (1979) 8，1222-1231

5) J.G. Garland and P. R. Kirkwood ; Met. Const. 7 (1975) 5, 275-283

6）金沢，中島他；鉄と距，61 (1975）11，2589-2604

7)上田，船越他；鉄之鋼，64 (1978）2，303-312

8）大谷，没辺；鉄上鍓，64 (1978) 14，2205-2214

9）渡辺，鉿木他；本誌，51（1982）2，118-126

10) 田中；JSSC, 9 (1973) $95,18-20$

\title{
極低 $(\mathrm{P}, \mathrm{S})$ 系 $9 \% \mathrm{Ni}$ 鋼溶接熱影響部の靫性*
}

\author{
渡邊 之**，小島 敏文**, 鈴木 元昭** \\ Toughness of HAZ of Extra Low Impurity Type 9\% Nickel Steel*
}

by Itaru Watanabe**, Toshifumi Kojima** and Motoaki Suzuki**

\begin{abstract}
In the previous paper, the authors conducted the coil-spring loading 3-point bending COD test and the large sacle tests on the $9 \%$ nickel steel weldments and determined that the weld-HAZ itself had satisfactorily high toughness to avoid the initiation of brittle fracture at cryogenic temperatures down to $-196^{\circ} \mathrm{C}$.

This paper describes further studies conducted on the $9 \%$ nickel steels including the extra low impurities one to bear out the superior weld-HAZ toughness from the metallurgical view points. Fracture toughness expressed in terms of CTOD and Charpy-V energy value was revealed to be significantly improved with the decreasing of phosphorous content in the region below $0.005 \%$.

The relation of fracture toughness and the microstructures which form the weld-HAZ structure were evaluated qualitatively by paying special attention to the reverse martensitic transformation mode during heating. As a result, it was evidenced that the superior weld-HAZ toughness depended on mainly its matrix structure, as low carbon Ni contained cellular martensite. The island-like martensite observed in microstructure of specimens subjected to heating to the temperatures, 700 to $900^{\circ} \mathrm{C}$ was identified as high carbon twinned martensite by the electron diffraction pattern analysis. The microstructure of specimens subjected to beating to $1350^{\circ} \mathrm{C}$ contains a little upper bainite.
\end{abstract}

1. 緒

言

溶接構造物の脆性破壊に対する抵抗性を論じる場合， 最脆化部の性質それ自身と，最脆化部を含めた溶接継手 全体としての破壊挙動のそれぞれに着目した検討が必要 である.

筆者らは前報1で主に LNG 貯槽の建造に使用される 極低温用 $9 \% \mathrm{Ni}$ 鋼に関し，オーステナイト系溶接金属 との異材継手およびフェライト系溶接金属との共金継手

*原稿受付 昭和58年 3 月 3 日（全国大会論文発表講窗）

**正 具 日本鋼管(株) Member, Nippon Kokkan K. K.
のそれぞれを用いて破壊勒性試験を行い，溶接熱影響部 自身の脆性破壊に対する抵抗性の評価を試みた。そてで はとくにバ亦荷重系を用いた小型三点曲げ COD 試験 ならびに大型腕性破壊試験を実施し，ポップイン破壊挙 動に着目した破塄勒性評価を行った。

それらの検討を通じて, $9 \% \mathrm{Ni}$ 鋼溶接熱影響部が使用 目的に適合した温度領域で優れた破壊鞇性を有すること が実証された. 併せて $9 \% \mathrm{Ni}$ 鋼製 $\mathrm{LNG}$ 貯槽の構造物 としての安全性が， $9 \% \mathrm{Ni}$ 銅溶接継手がオーステナイ 卜系溶接金属との異材継手である特異性によって保証さ 